\title{
VALORIZAÇÃO DOS FINOS DE CARVÃO VEGETAL NO DESENVOLVIMENTO DE FRITA CERÂMICA PARA FORMULAÇÃO DE ENGOBE
}

\author{
Luara Pires Bernardini ${ }^{1 *}$ Aline Resmini Melo ${ }^{2}$ Débora De Pellegrin Campos ${ }^{3}$ \\ Josiane da Rocha Silvano das Neves $^{4}$ Jeorge Luiz Coelho ${ }^{5}$ \\ Morgana Nuernberg Sartor Faraco ${ }^{6}$ \\ 1Departamento de Engenharia Química, Faculdade Satc \\ ${ }^{2}$ Empresa Colorminas \\ *e-mail: luarabernardini@gmail.com
}

\section{Resumo:}

A produção de carvão vegetal gera além do produto final um resíduo: os finos. Os finos são um material fino, sem valor agregado e sem destino específico, tornando-o barato. O objetivo deste estudo foi atribuir valorização a esse resíduo, fornecido por uma empresa da região Sul de Santa Catarina, utilizando-o como matéria-prima no processo produtivo de outro segmento, o colorifício. A partir de análises de caracterização da amostra do resíduo, elaborou-se uma frita cerâmica empregando $13 \%$ do resíduo como matéria prima. A partir do desenvolvimento da frita, foram realizados testes para otimização de um engobe de uso comercial. Foram analisadas 13 formulações, sendo que o melhor teste escolhido, contendo $3 \%$ da frita desenvolvida, foi produzido em semi-industrial, ou seja, testado em cerâmica para avaliação de parâmetros de qualidade. $O$ engobe apresentou reologia (densidade, viscosidade e resíduo) e dilatação adequadas comparando-se com o padrão. O teste apresentou maior fusibilidade, entretanto com menos brancura e com mancha d'água mais perceptível o que não descaracteriza o resultado final satisfatório do produto. A viabilidade técnica da utilização dos finos como matéria-prima na produção de frita cerâmica foi comprovada, aliando o desenvolvimento de novos produtos comerciais com a sustentabilidade de processos produtivos de outros segmentos.

Palavras-chave: Resíduo. Desenvolvimento. Frita. Engobe cerâmico.

\section{INTRODUÇÃO}

O carvão vegetal é utilizado desde a antiguidade até os dias atuais no aquecimento de churrasqueiras, fogões a lenha, lareiras, entre outros. O Brasil corresponde por cerca de $1 / 3$ da produção mundial de carvão vegetal e esse é responsável por 30\% da produção de ferro-gusa no país.

O processo de fabricação do carvão vegetal gera como resíduo os finos, que não é reutilizado no processo. A necessidade de buscar uma utilização para esse resíduo objetivou esse trabalho, no qual será desenvolvida uma frita cerâmica utilizando como matéria-prima os finos de carvão vegetal e posteriormente será testada numa formulação de engobe. A empregabilidade desse resíduo no colorifício proporciona o desenvolvimento de novos produtos e fornece ao resíduo maior valor agregado, tornando o processo mais sustentável e reduzindo custos industriais.

\section{REVISÃO BIBLIOGRÁFICA}

Nesta secção serão explanados assuntos como: histórico, estatísticas de produção, processo produtivo e análises características do carvão vegetal, assim como abordagens sobre colorifício e suas particularidades. 


\subsection{HISTÓRICO E DADOS DE PRODUÇÃO DO CARVÃO VEGETAL}

$\mathrm{Na}$ época da sociedade primitiva o homem utilizava pedaços de madeira em fogueiras com o intuito de se aquecer e iluminar a caverna, e esse processo gerava como produto a madeira queimada de coloração preta e frágil. Posteriormente o homem percebeu que a queima da madeira já queimada não produzia tanta fumaça e nem chama, ou seja, concedendo calor de uma forma mais controlável do que citada anteriormente, marcando assim a descoberta do carvão vegetal (JUVILLAR, 1980).

O fogo também era utilizado para cozer alimentos, como fonte de luz e calor para tratamento de materiais que posteriormente seriam empregados na confecção de armas e ferramentas (SANTOS; HATAKEYAMA, 2012).

A utilização do carvão intensificou-se com a evolução da humanidade, e mesmo sendo substituído por combustiveis fósseis em alguns casos, em muitos lares de países subdesenvolvidos ainda é o combustível imprescindível em churrasqueiras, fogões a lenha, lareiras, aquecedores, entre outros, seja por motivos financeiros ou econômicos (GUARDABASSI, 2006).

Ainda nos dias atuais com outras possibilidades, o carvão vegetal tem utilidade relevante na produção de certos fundidos de ferro, como ferro-gusa. $O$ Brasil responde por cerca $1 / 3$ da produção mundial de carvão vegetal e esse é responsável por $30 \%$ da produção de ferro-gusa no país. O ferro-gusa é a liga metálica que dá origem ao aço utilizado em cabos, navios, trens, máquinas, veículos entre outros produtos (SANTOS; HATAKEYAMA, 2012; OLIVEIRA, 2011).

Na produção do ferro-gusa o carvão cumpre duas funções: como combustível gerando o calor suficiente para operação do alto forno da siderúrgica e como agente químico para retirar oxigênio durante o processo. Utiliza-se carvão vegetal pois é isento de enxofre, elemento químico presente no carvão mineral (SANTOS; HATAKEYAMA, 2012).

Segundo dados do PEVS (Produção da Extração Vegetal e da Silvicultura) a Silvicultura no Brasil (área de conhecimento que destina-se à recuperação de florestas) contribuiu com $\mathrm{R} \$ 14,1$ bilhões, enquanto a extração vegetal (coleta de produtos em florestas e matas nativas) com $\mathrm{R} \$ 4,4$ bilhões somando um total de $\mathrm{R} \$ 18,5$ bilhões no ano de 2016 (IBGE, 2016).

Segundo IBGE (2016), no ano de 2016 a produção de carvão vegetal foi de 5 milhões de toneladas o que corresponde a 53,3 milhões de $\mathrm{m}^{3}$, sendo que $98,9 \%$ foi procedente de plantios de eucalipto e apenas $1,1 \%$ derivado de mata nativa. A área ocupada por florestas plantadas foi de 10 milhões de hectares, num aumento de $0,9 \%$ em comparação a 2015 , sendo que $75,3 \%$ são áreas de eucalipto e $20,7 \%$ de pinus.

Segundo dados de uma Empresa do sul do estado de Santa Catarina no ano de 2017 foi produzido cerca de $2.277 \mathrm{~m}^{3}$, aproximadamente 296 toneladas de carvão vegetal sendo que $10 \%$, ou seja, 29,6 toneladas foram de material fino, considerado como resíduo da produção. Na Fig. 1 é retratado o carvão vegetal e seu rejeito (finos). 


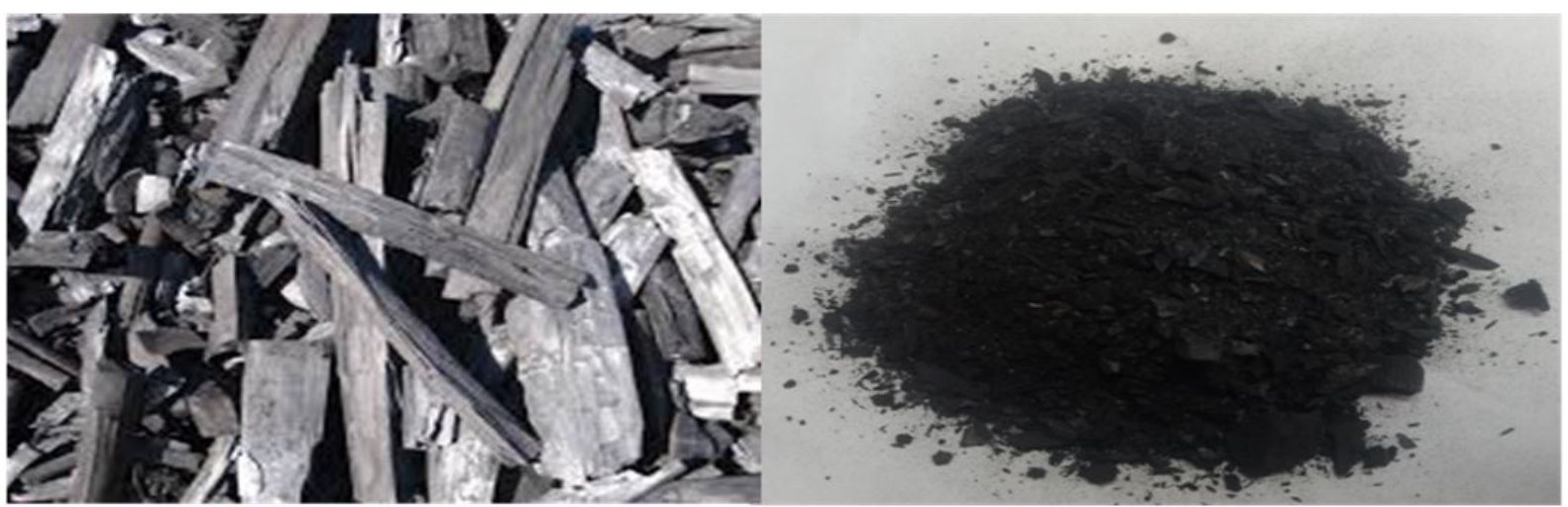

Figura 1: Carvão vegetal e finos (resíduo a ser valorizado). Fonte: Do autor (2018)

O resíduo pode ser descrito como todo material, substância ou produto que resta de um processo de produção, exploração, transformação ou de utilização, sendo muitas vezes descartado (CEMIN, 2010).

É cada vez mais frequente o estudo em soluções que minimizem os resíduos em indústrias, seja pela melhoria de seus processos reduzindo custos industriais ou por exigências de órgãos ambientais adequando as indústrias a sistemas sustentáveis. Quando não é possível reutilizar o resíduo no próprio processo, ele torna-se uma matéria-prima barata e que pode ser comercializado para empresas de outros segmentos, como é o caso do finos (SASAKI, LIMA, QUINÁIA, 2014).

\subsection{PROCESSO PRODUTIVO DO CARVÃO VEGETAL}

O carvão vegetal, ou também conhecido como carvão artificial, cujo nome botânico é Carbo activatu é originado da queima da madeira. O ciclo de tranformação da madeira em carvão ocorre em 4 etapas, sendo elas: carregamento do forno, processo de carbonização, processo de resfriamento e descarga do carvão. Entretanto, as práticas como silvicultura e manejo do povoamento florestal, ocorrem antes do processo de transformação e são determinantes para qualidade do carvão (LOUREIRO, 2014).

\subsubsection{Silvicultura e manejo do povoamento florestal}

Segundo LOUREIRO (2014), alguns produtores ainda utilizam madeira oriunda de florestas nativas para produção de carvão vegetal, porém nos últimos anos houve a substituição pela madeira de florestas plantadas por inúmeros motivos, são eles:

- Incentivos fiscais do governo federal (meados dos anos 60) e a obrigatoriedade legal (Código florestal) das siderúrgicas de serem sustentáveis;

- Controle de características desejáveis como: a forma, umidade, dimensões e teor de carbono. Itens que não podem ser controlados na madeira nativa;

- A madeira nativa produz carvão com qualidade variada, devido as espécies que a produz, e o carvão de floresta plantada é homogêneo, promovendo qualidade e viabilizando melhor preço no produto final;

- A madeira de floresta nativa gera mais cinzas quando comparadas a madeira de floresta plantada, devido a diferença nas densidades das espécies.

A maioria das empresas utilizam na produção de carvão vegetal florestas plantadas de Eucalyptus e/ou Pinus, todavia o manejo da floresta varia de acordo com a região e a empresa. A grande utilização de Eucalyptus deve-se ao seu rápido crescimento (sete anos) e boa adaptação a diferentes condições ambientais. O gênero Eucalyptus possui aproximadamente 70 gêneros e 3.000 espécies, e as mais utilizadas no Brasil são: E. grandis, E. saligna, Corymbiacitriodora, E. camaldulensise, E. urophylla, assim como seus híbridos (SANTOS, 2010). 
Em seguida do plantio, ocorre o corte, o desgalhamento das árvores e o embandeiramento. No embandeiramento as árvores permanecem por 90 dias enfileiradas no campo com o objetivo de secá-las. Por meio de caminhões, a madeira seca é levada para próximo do forno de carvoejamento, para iniciar as etapas do processo de produção de carvão vegetal (LOUREIRO, 2014).

\subsubsection{Carregamento do forno}

Na primeira etapa a lenha é empilhada na posição horizontal no interior do forno, sendo que esse empilhamento pode ser feito por trabalho manual ou mecanizado utilizando gruas, que retiram a lenha do lado do forno e as empilham no seu interior (LOUREIRO, 2014).

Existem diferentes tipos de fornos, os mais conhecidos são os fornos de rabo quente ou meia laranja. O forno "rabo quente" ou "meia laranja" é o mais utilizado por pequenos e médios produtores, cerca de $80 \%$, devido ao seu baixo custo e fácil construção, mas apresenta baixa produtividade (4 a $8 \mathrm{~m}^{3}$ de carvão) (LOUREIRO, 2014; CEMIN, 2010).

\subsubsection{Processo de carbonização}

A carbonização, ou queima da madeira, é um processo químico conhecido a 10.000 anos, onde seu propósito é aumentar o teor de carbono fixo na madeira por meio de tratamento térmico. É a etapa primordial do processo de fabricação do carvão e se não for bem sucedida o carvão não atingirá a qualidade e produtividade esperada (BENITES et al., 2009).

$\mathrm{Na}$ carbonização os resíduos ligno-celulósicos sofrem alterações químicas e físicas irreversíveis. Além do produto principal que é carvão vegetal outros subprodutos também são produzidos como: monóxido e dióxido de carbono, metano, vapor d'água, alcatrão, ácido acético entre outros (CEMIN, 2010).

Nessa segunda etapa, que é controlada, inicia-se com a ignição do forno. A fumaça primeiramente é esbranquiçada, constatando que a lenha está perdendo umidade, com a presença de vapor d'água, $\mathrm{CO}$ e $\mathrm{CO}_{2}$ (vapores incondensáveis) e em seguida torna-se amarelada indicando a presença de alcatrão e ácido pirolenhoso (vapores condensáveis) e por fim torna-se azulada indicando presença de $\mathrm{CO}$ e $\mathrm{CO}_{2}$ (ASSIS, 2007).

Segundo CEMIN (2010) a carbonização pode ser dividida em quatro etapas conforme a temperatura:

1) Inferior a $200{ }^{\circ} \mathrm{C}$ : secagem e início da decomposição térmica da madeira;

2) De 200 a $280{ }^{\circ} \mathrm{C}$ : predomínio das reações endotérmicas, com liberação de ácido acético, metanol, água, $\mathrm{CO}_{2}$, entre outros.

3) De 280 a $500^{\circ} \mathrm{C}$ : predomínio das reações exotérmicas, com a liberação de gases combustíveis como $\mathrm{CO}$, $\mathrm{CH}_{4}$, entre outros.

4) Acima de $500^{\circ} \mathrm{C}$ : nessa etapa o carvão já está estável e pequenas quantidades de materiais voláteis como $\mathrm{H}_{2}$, são liberadas.

A qualidade do carvão está diretamente relacionada a temperatura final de carbonização. Quanto maior for a temperatura final, mais elementos voláteis são eliminados, contudo o aumento rápido na temperatura faz com que haja a expansão rápida dos gases dentro da madeira e impede que ocorra reações secundárias, o que reduz o teor de carbono no produto final (LOUREIRO, 2014).

\subsubsection{Processo de resfriamento}

Ao final do processo de carbonização inicia-se a etapa de resfriamento onde são abertos brechas possibilitando a entrada de ar para que ocorra a sequência de nebulizações. O intuito é acelerar o resfriamento do forno até que alcance a temperatura de $40^{\circ} \mathrm{C}$ permitindo a descarga do carvão (ASSIS, 2007). 


\subsubsection{Descarga do carvão}

Nessa última o carvão é retirado gradativamente no sentido da porta para o fundo do forno com movimentos que provoquem pequena vibração, devido a fragilidade do material. Nesse momento ainda é feito a limpeza das caneletas retirando a borra de alcatrão, entre outros líquidos e a vedação de possíveis fissuras decorrentes do processo de resfriamento (LOUREIRO, 2014).

\subsection{MÉTODO DE ANÁLISE QUÍMICA DO CARVÃO VEGETAL}

A análise química imediata do carvão vegetal consiste na determinação das suas características em termos de: umidade, matérias voláteis, cinzas e carbono fixo de acordo com método ASTM D-1762-64 (reaprovado em 1990) - "Chemical Analysis of Wood Charcoal" (CETEC, 1982).

\subsubsection{Umidade}

Esta análise baseia-se na perda de substâncias voláteis por dessecação em estufa na temperatura de $105^{\circ} \mathrm{C}$ por intervalo de 60 minutos. A perda de peso da amostra é determinada segundo a Eq. (1) (Adapatado CETEC, 1982).

$\boldsymbol{U m}(\%)=\frac{A-B}{A} \times 100$

Onde:

$\mathrm{A}=$ Peso do carvão seco ao ar ( $\mathrm{g})$;

$\mathrm{B}=$ Peso do carvão seco em estufa $(\mathrm{g})$.

\subsubsection{Determinação de matérias voláteis}

Este método baseia-se na caracterização do percentual de matérias voláteis em forno mufla a $950^{\circ} \mathrm{C}$ durante 7 minutos. A perda de peso da amostra é determinada segundo a Eq. (2) (CETEC, 1982).

Matérias voláteis $(\%)=\frac{A-B}{A} \times 100$

Onde:

$\mathrm{A}=$ Peso do carvão seco em estufa a $105^{\circ} \mathrm{C}(\mathrm{g})$;

$\mathrm{B}=$ Peso do carvão após tratamento a $950^{\circ} \mathrm{C}(\mathrm{g})$.

\subsubsection{Determinação do teor de cinzas}

O teor de cinzas é determinado, pelo resíduo após combustão de constituintes orgânicos e oxidação dos inorgânicos da amostra em forno mufla a $750^{\circ} \mathrm{C}$ por 2 horas, segundo a Eq. (3) (CETEC, 1982).

$\operatorname{Cinzas}(\%)=\frac{C}{A} x 100$

Onde:

$\mathrm{A}=$ Peso do carvão seco em estufa a $105^{\circ} \mathrm{C}(\mathrm{g})$;

$\mathrm{C}=$ Peso do resíduo $(\mathrm{g})$.

\subsubsection{Determinação de carbono fixo}

O teor de carbono fixo é obtido conforme Eq. (4) (CETEC, 1982). 
Bernardini, L. P. et al.

Carbono fixo $(\%)=100-($ Matérias voláteis + Cinzas $) \%$

\subsection{COLORIFÍCIO}

Os colorifícios constituem a cadeia produtiva de diferentes segmentos da indústria cerâmica, suprindo-as com matérias-primas que são empregadas na formação da superfície e na decoração das peças cerâmicas (JUNIOR et al., 2010).

O colorifício, integra o segmento de materiais não-metálicos da indústria de transformação, juntamente com outras indústrias como cerâmica vermelha, revestimentos cerâmicos, indústria cimenteira, sanitários, sendo cadeias produtivas que abrangem o complexo da construção civil (JUNIOR et al., 2010).

O termo colorifício caracteriza as empresas que produzem esmaltes, fritas e corantes cerâmicos, podendo-se adicionar segmentos como granilhas, tintas, pastas serigráficas, engobes entre outros (HERAS, 2002).

A Fig. 2 retrata, por meio de microscopia eletrônica de varredura, a seção transversal típica de um revestimento cerâmico, onde é possível destacar suas camadas constituintes, sendo elas: suporte cerâmico (base), engobe e esmalte, ressaltando que somente as camadas de engobe e esmalte fazem parte do segmento de colorifícios. A camada do suporte cerâmico é de responsabilidade das empresas cerâmicas (MONTE et al., 2008; JUNIOR et al., 2010).

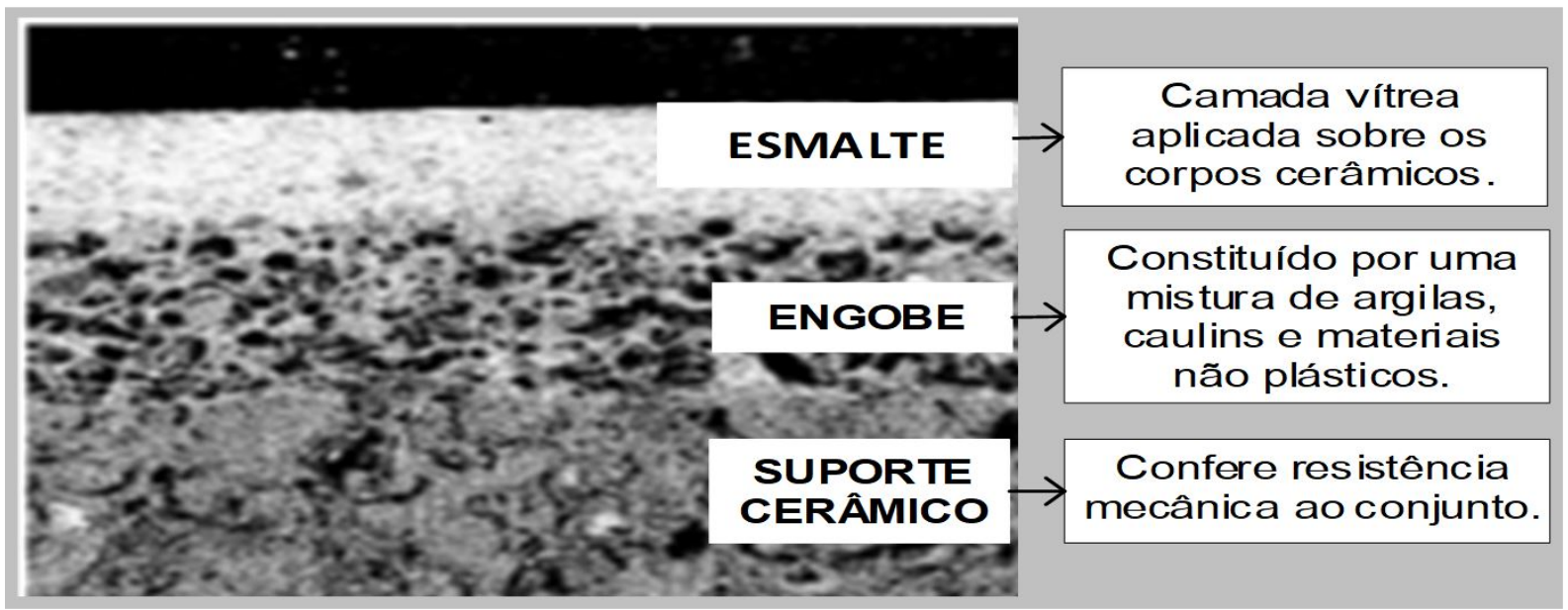

Figura 2: Camadas que compõem o revestimento cerâmico. Fonte: Adaptado de Monte et al. (2008, p.1181)

Já a Fig. 3 representa os segmentos de mercado de colorifícios expresso em volume, exaltando que os compostos e esmaltes são os principais insumos comercializados (MONTE et al., 2008; JUNIOR et al., 2010). 


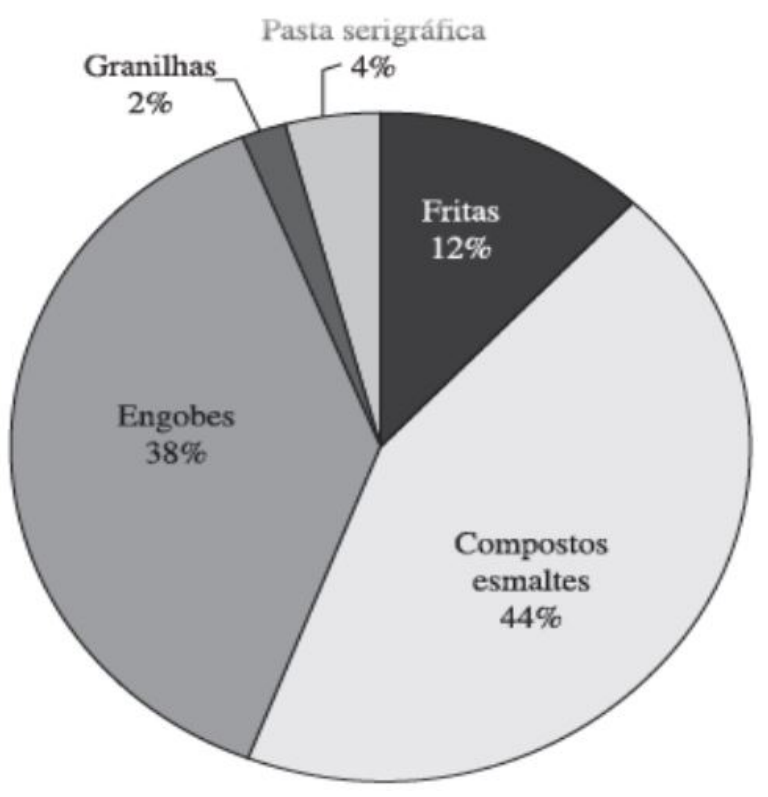

Figura 3: Representação do mercado. Fonte: Junior et al. (2010, p.14)

A frita apresenta um percentual de apenas $12 \%$ no gráfico, entretanto é a matéria-prima dos outros produtos, caracterizando-se como principal produto fornecido pelos colorifícios.

\subsection{FRITAS CERÂMICAS}

As empresas do ramo de colorifício apresentam como principal produto as fritas cerâmicas, podendo ser utilizadas isoladamente ou em formulações juntamente com outras matérias-primas para produção de engobes, esmaltes, granilhas, entre outros (COELHO, 2014).

A frita cerâmica, será foco neste estudo, pois esta será desenvolvida utilizando resíduos (finos), proveniente do carvão vegetal, na sua formulação.

As fritas cerâmicas são materiais vítreos, insolúveis em água, obtidas a partir da fusão de matériasprimas em temperaturas altas $\left(1500^{\circ} \mathrm{C}\right)$ seguida do resfriamento rápido em ar ou água (JUNIOR et al., 2010; SÁNCHES, 1997).

Após a fritagem, ou seja, seu processo de fabricação, a frita passa por outros processos com intuito de obter um produto homogêneo para ser aplicado na superfície do corpo cerâmico e ser submetido à queima controlada, variando entre 850 e $1220^{\circ} \mathrm{C}$ (COELHO, 2014).

A utilização das fritas em produtos cerâmicos proporcionam flexibilidade na aplicação das matériasprimas utilizadas na cerâmica, pois muitas fritas possuem matérias-primas que são utilizadas em outros processos com as mesmas, aumentam o intervalo de queima dos esmaltes, concedem uma maior uniformidade no vidrado, diminuem o aparecimento de defeitos superficiais oriundos do corpo cerâmico e possibilitam ao produto acabado uma textura superficial mais lisa, brilhante e impermeável (ZANATTA, 2013).

\subsection{GRANILHAS}

As granilhas são fritas que passaram pelo processo de moagem e são diferenciadas granulometricamente ( 0,15 a $2 \mathrm{~mm})$, sendo que o intervalo é definido com base nos efeitos que se pretende alcançar no produto final. Podem ser transparentes, mates, opacas ou coloridas e sua coloração é feita durante a fusão da frita ou por acréscimo de pigmentos (corantes) cerâmicos (SARABANDO, OLIVEIRA, LABRINCHA, 2011). 
Conferem aos produtos maior variabilidade estética, como efeitos de textura, rugosidade, cor, entre outros e são aplicadas ao final de toda a linha de esmaltação e decoração (SARABANDO, OLIVEIRA, LABRINCHA, 2011; LIMA, 2007).

\subsection{ESMALTES}

O esmalte é, basicamente, uma mistura de matérias-primas com fritas de diferentes especificações, com plastificantes, como argilas e caulins, e aditivos orgânicos, como cola. Sua composição passa pelo processo de moagem controlado, formando uma suspensão aquosa, denominada barbotina e que são aplicadas sobre o engobe e biscoito cerâmico. Durante o processo de queima o esmalte funde-se resultando numa cobertura vitrificada impermeável (LIMA, 2007; COELHO, 2014).

Essa cobertura deve garantir bom espalhamento, cobrindo toda superfície e uma boa adesão ao suporte, proporcionando resistência à placa cerâmica à absorção de água, aumentando a resistência mecânica e fornecendo efeitos estéticos como brilho e cor. Os esmaltes podem ser transparentes e brilhantes, opacos (mates) ou brancos (LIMA, 2007; COELHO, 2014).

\subsection{ENGOBES}

Entre o esmalte e o suporte cerâmico existe uma cobertura argilosa com acabamento fosco, que pode ser impermeável ou permeável, branco ou colorido: o engobe. $\mathrm{O}$ engobe tem por principais funções ocultar a cor e eliminanar possíveis imperfeições do suporte cerâmico (COELHO, 2014; MONTE, 2008).

A produção do engobe é semelhante ao esmalte, contudo é uma suspensão mais diluída, ou seja, constituída por um percentual menor de fritas adicionada a feldspatos, quartzo, silicato de zircônio e argilas brancas (plásticas e refratárias) (LIMA, 2007).

Neste estudo o engobe será o produto cerâmico fabricado, utilizando como matéria-prima a frita desenvolvida com finos de carvão vegetal.

\subsection{ENSAIOS DE CARACTERIZAÇÃO DO MATERIAL}

$\mathrm{Na}$ elaboração de formulações de engobes alguns ensaios são essenciais como: densidade (mensurada através do picnômetro), tempo de escoamento (mensurada através do copo Ford) e controle de resíduo, antes da queima do suporte cerâmico.

Após a queima do suporte cerâmico são avaliados o aspecto visual (avaliação das peças após queima), a marca d'água e a análise termodilatométrica.

A análise termodilatométrica é realizada no equipamento denominado dilatômetro. A dilatação térmica é característica de cada material e é expressa por um fator que depende de sua temperatura, o coeficiente de dilatação.

\section{PROCEDIMENTOS EXPERIMENTAIS}

O procedimento experimental deste estudo foi realizado na Empresa Colorminas Coloríficio e Mineração S.A.

Os ensaios foram realizados no laboratório de Controle de Qualidade e a maioria das análises foram executadas no laboratório de Pesquisa e Inovação Tecnológica, ambos pertencentes à Empresa Colorminas Coloríficio e Mineração S.A. em Içara (SC). A análise de fluorescência de raio X foi realizada no SENAI, em Criciúma (SC).

O fluxograma do procedimento experimental está dividido em cinco etapas. 
O estudo iniciou com o recebimento do resíduo oriundo de uma empresa da região Sul de SC. Após o recebimento, o resíduo foi preparado para posterior realização das suas análises de caracterização.

Mediante aos resultados de caracterização foi elaborado e produzido uma frita cerâmica utilizando o resíduo como matéria-prima. A frita produzida foi empregada no desenvolvimento de um engobe cerâmico. A partir do engobe produzido foram realizadas análises de qualidade do produto, finalizando com a avaliação dos resultados obtidos.

As etapas deste procedimento experimental estão descritas no fluxograma, conforme a Fig. 4.

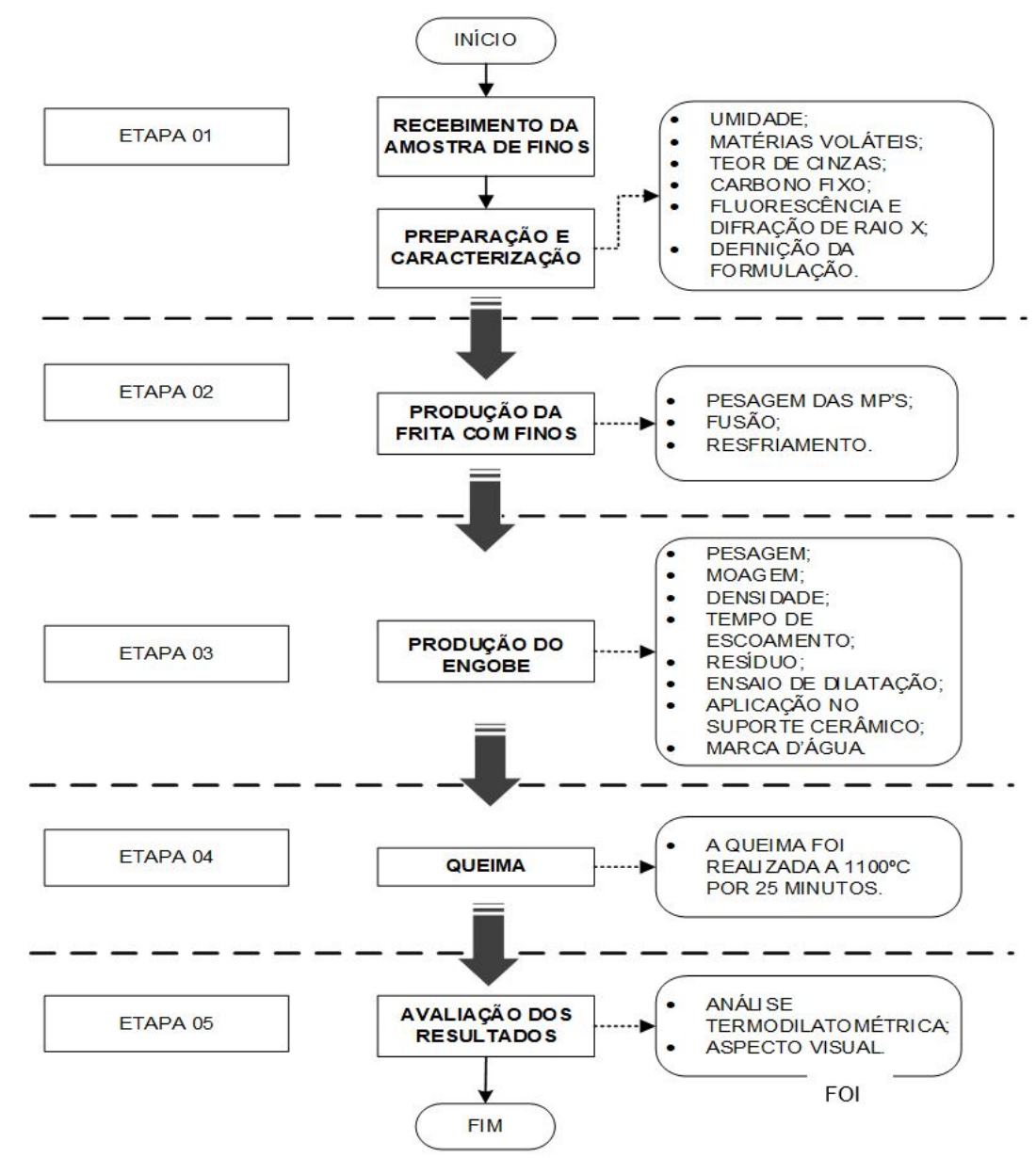

Figura 4: Fluxograma do procedimento experimental. Fonte: Do autor (2019)

\section{RESULTADOS E DISCUSSÕES}

Os resultados serão apresentados em cincos etapas conforme descritos no procedimento experimental.

\subsection{ETAPA 1: RECEBIMENTO, PREPARAÇÃO E CARACTERIZAÇÃO}

A amostra de finos de carvão vegetal disponibilizada pela empresa da região foi moída em moinho periquito (proporcionando homogeneização ao material) para posteriores análises de caracterização.

A composição da amostra de finos fornecida é proveniente de madeiras como Eucalyptus e Pinus.

As espécies de Eucaliptos e Pinus são as mais utilizadas na região sul do país devido à fácil adaptação ao clima vigente e por serem espécies de rápido crescimento. 
Bernardini, L. P. et al.

\subsubsection{Método de análise química do material}

A Tab.1 exibe os resultados das análises de umidade, matérias voláteis, teor de cinzas e carbono fixo da amostra de finos do carvão vegetal.

Tabela 1: Caracterização do resíduo.

\begin{tabular}{cc}
\hline Variáveis & Resultados (\%) \\
\hline Umidade & 2,48 \\
Matérias voláteis & 57,99 \\
Teor de cinzas & 81,79 \\
Carbono fixo & 39,78 \\
\hline
\end{tabular}

Fonte: Do autor (2019)

A partir das análises dos resultados obtidos observou-se que o material apresenta um baixo percentual de umidade $(2,48 \%)$, entretanto um alto percentual de teor de cinzas $(81,79 \%)$, o que demonstra que o carvão apresenta um alto resíduo de óxidos minerais. A Fig. 5 apresenta as amostras de finos de carvão vegetal que foram submetidas às análises de umidade, teor de cinzas e matérias voláteis da esquerda para direita.

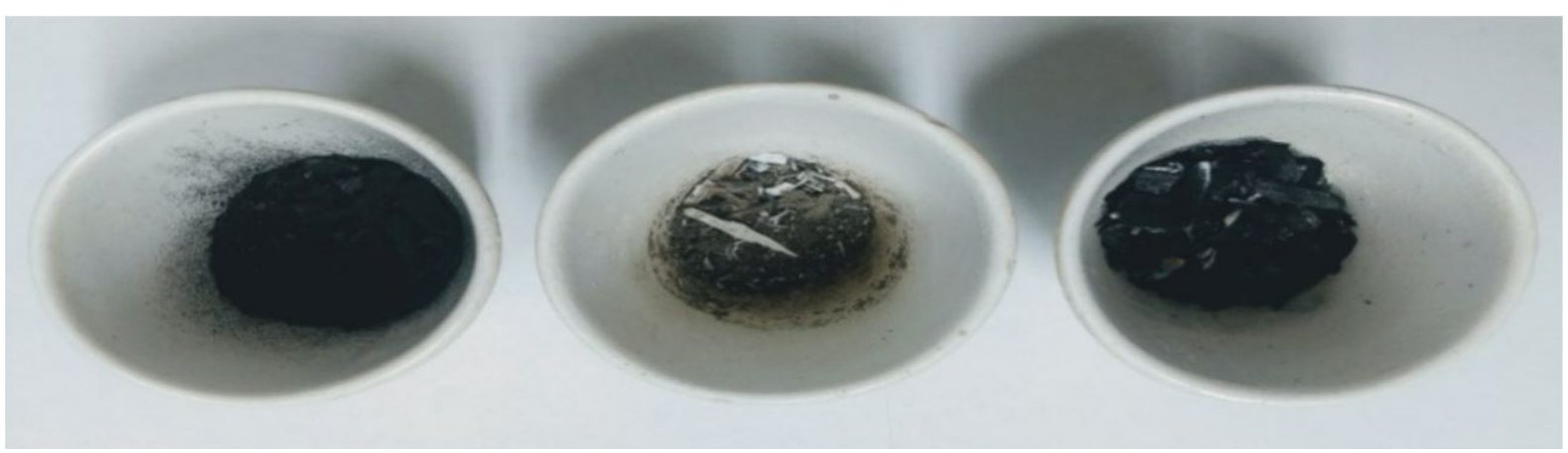

Figura 5: Finos após análise de umidade, teor de cinzas e matérias voláteis respectivamente. Fonte: Do autor (2019)

\subsubsection{Análise química por Fluorescência de Raios X dos finos de carvão vegetal}

A Tab.2 apresenta a análise química, obtida por meio da técnica de fluorescência de raio X em amostra de finos de carvão.

Tabela 2: Análise química qualitativa dos finos de carvão vegetal.

\begin{tabular}{ccc}
\hline Elementos & Elementos químicos & Percentual (\%) \\
\hline Majoritários & $\mathrm{Al} ; \mathrm{Si}$ Ca & $10-100$ \\
Pequeno percentual & $\mathrm{Na} ; \mathrm{Mg} ; \mathrm{P} ; \mathrm{S} ; \mathrm{Cl} ; \mathrm{K} ; \mathrm{Ti} ; \mathrm{Mn} ; \mathrm{Fe} ; \mathrm{Sr}$ & $0,1-9,99$ \\
Traços & $\mathrm{Cu} ; \mathrm{Zn} ; \mathrm{Ba}$ & $<0,09$ \\
\hline
\end{tabular}

Fonte: Do autor (2019)

A análise apresentou os óxidos de alumínio, silício e cálcio como majoritários, ou seja, com percentuais acima de $10 \%$. O óxido de silício é um dos óxidos em maior abundância no planeta. O óxido de alumínio é encontrado em compostos e o óxido de cálcio faz parte dos minerais encontrados em rochas. A junção desses óxidos propicia melhora nas propriedades químicas e mecânicas do material. Vale ressaltar que o resíduo apresentou um pequeno percentual de óxido de ferro, o que é bem visto, já que o ferro é um agente contaminante. 


\subsubsection{Análise mineralógica por Difração de Raios X}

A Fig.6 aponta o difratograma, ou seja, as fases mineralógicas encontradas na amostra dos finos de carvão vegetal.

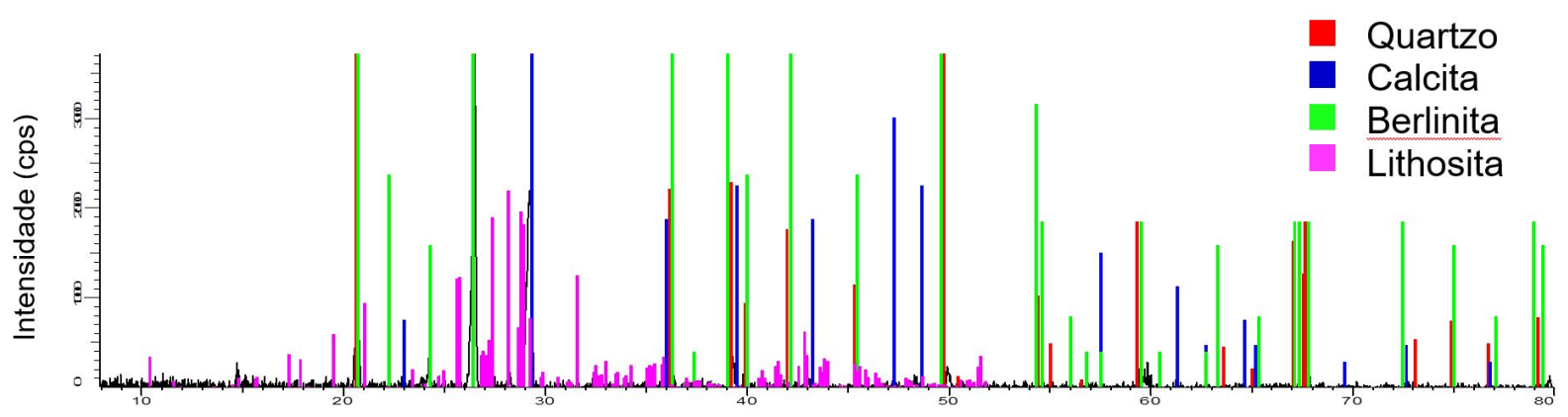

Ângulo $2 \theta$ (graus)

Figura 6: Difratograma de raio X da amostra de finos de carvão vegetal. Fonte: Do autor (2019)

A amostra apresentou 50,2\% de cristalinidade, sendo que as fases encontradas foram quartzo, calcita, berlinita e lithosita. A fase de quartzo refere-se ao óxido de silício $\left(\mathrm{SiO}_{2}\right)$ encontrado em composições de rochas magmáticas, sedimentares e metamórficas, na frita proporciona ação vitifricante, pois é conhecida como "vitrificante universal". A fase de calcita refere-se ao carbonato de cálcio $\left(\mathrm{CaCO}_{3}\right)$, sendo um constituinte do calcário de rochas sedimentares e carbonatos, proporcionando fundência a frita. A fase berlinita refere-se ao mineral de fosfato de alumínio $\left(\mathrm{AlPO}_{4}\right)$ e age como estabilizante na frita. A lithosita refere-se ao silicato com fórmula $\mathrm{K}_{6} \mathrm{Al}_{4} \mathrm{Si}_{8} \mathrm{O}_{25} \cdot \mathrm{H}_{2} \mathrm{O}$.

A análise química reporta os elementos químicos presentes no material, mas não a forma como estão ligados. O propósito da análise mineralógica é exatamente esse, mostrar como os átomos estão ligados por meio das fases encontradas, contribuindo assim para a caracterização do material. As fases encontradas são coerentes aos finos de carvão vegetal, devido aos seus minerais presente na estrutura da vegetação, assim como a análise química expressa anteriormente.

\subsubsection{Definição da formulação da frita}

Com base nos resultados obtidos foi elaborada uma formulação de frita mate para massa seca, conforme apresentada na Tab.3.

Tabela 3: Formulação da frita desenvolvida com adição de resíduo de carvão vegetal.

\begin{tabular}{cc}
\hline Matéria-prima & Percentual (\%) \\
\hline Carbonato de Bário & $2-3$ \\
Tetraborato de sódio & $12-13$ \\
Ácido bórico & $3,5-4,5$ \\
Feldspato com lítio & $18-19$ \\
Feldspato potássico & $14-15$ \\
Finos de carvão vegetal & $\mathbf{1 3 - 1 4}$ \\
Quartzo & $27-28$ \\
Vidro sodo-cáustico & $5-6$ \\
\hline
\end{tabular}

Fonte: Do autor (2019) 


\subsection{ETAPA 2: PRODUÇÃO DA FRITA CERÂMICA}

Após a pesagem, as matérias primas foram homogeneizadas e fundidas em cadinhos de mulita a $1500^{\circ} \mathrm{C}$ por 2 horas. Após a fusão o material fundido foi resfriado bruscamente em água, formando um material vítreo granulado, a frita. A Fig. 7 apresenta a frita produzida.

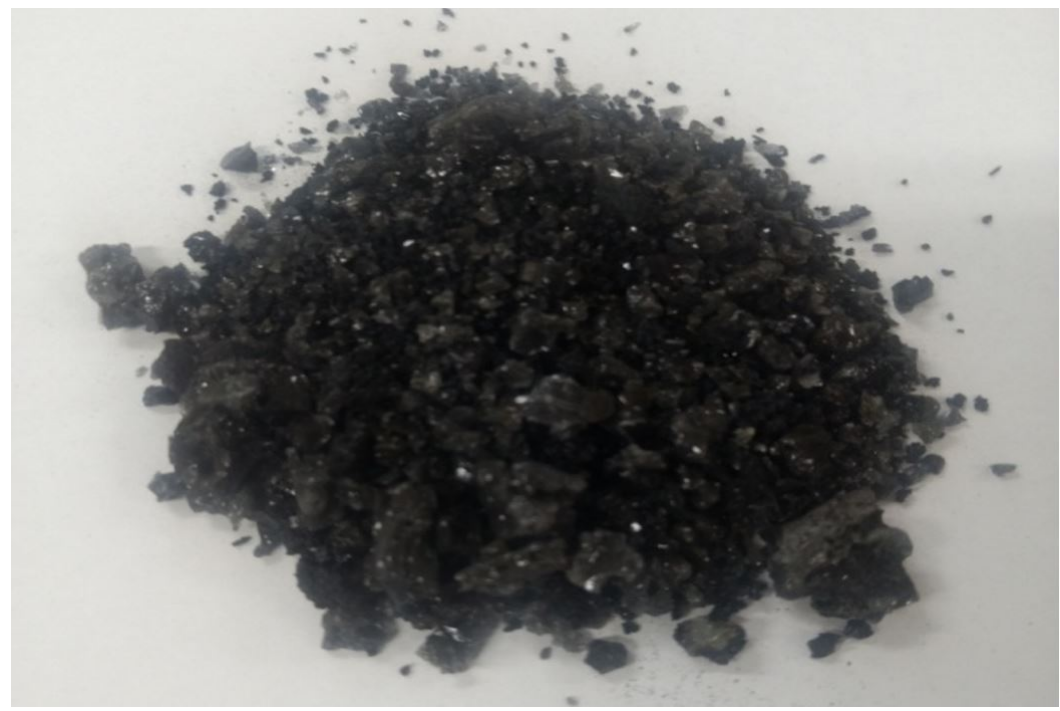

Figura 7: Frita produzida com finos de carvão vegetal. Fonte: Do autor (2019)

\subsection{ETAPA 3 E 4: PRODUÇÃO DO ENGOBE E QUEIMA}

Nesta secção será apresentada a formulação do engobe assim como os testes realizados para controle de qualidade.

\subsubsection{Formulação do engobe}

Elaboraram-se formulações de engobe branco utilizando a frita produzida, conforme os testes descritos na Tab.4. Os percentuais de frita produzida, assim como as outras matérias constituintes variaram com o intuito de avaliar e escolher o melhor teste.

Tabela 4: Formulação do engobe com frita desenvolvida com finos de carvão mineral.

\begin{tabular}{|c|c|c|c|c|c|c|c|c|c|c|c|c|c|}
\hline \multirow{2}{*}{ MP } & \multicolumn{13}{|c|}{ Percentual das matérias-primas (MP) em cada teste } \\
\hline & T1 & T2 & T3 & T4 & T5 & T6 & T7 & T8 & T9 & T10 & T11 & T12 & T13 \\
\hline A & 30 & 30 & 30 & 30 & 30 & 30 & 30 & 32 & 34 & 39 & 39 & 39 & 39 \\
\hline Frita & 12,5 & 7 & 7 & 7 & 7 & 5 & 5 & 3 & 3 & 3 & 3 & 3 & 3 \\
\hline $\mathrm{C}$ & 2 & 2 & 2 & 2 & 2 & 2 & 2 & 2 & 2 & 2 & 2 & 2 & 2 \\
\hline $\mathrm{D}$ & 4,25 & 4,25 & 4,25 & 4,25 & 4,25 & 4,25 & - & - & - & - & - & - & - \\
\hline $\mathrm{E}$ & 20,5 & 20,5 & 15 & 10 & 15 & 12 & 12 & 12 & 12 & 5 & 5 & 5 & 5 \\
\hline $\mathrm{F}$ & 6 & 6 & 6 & 6 & 6 & 6 & 6 & 6 & 6 & 6 & 6 & 6 & 6 \\
\hline $\mathrm{G}$ & 5 & 5 & 5 & 5 & - & - & - & - & - & - & - & - & - \\
\hline $\mathrm{H}$ & 3 & 3 & 3 & 3 & 3 & 3 & 3 & 3 & 3 & 3 & 3 & 3 & 3 \\
\hline I & 16 & 16 & 16 & 16 & 16 & 21 & 21 & 21 & 19 & 21 & 21 & 21 & 21 \\
\hline $\mathrm{J}$ & 0,05 & 0,05 & 0,05 & 0,05 & 0,05 & 0,05 & 0,05 & 0,05 & 0,05 & 0,05 & 0,05 & 0,05 & 0,05 \\
\hline $\mathrm{K}$ & 0,05 & 0,05 & 0,05 & 0,05 & 0,05 & 0,05 & 0,05 & 0,05 & 0,05 & 0,05 & 0,05 & 0,05 & 0,05 \\
\hline $\mathrm{L}$ & 0,35 & 0,35 & 0,35 & 0,35 & 0,35 & 0,35 & 0,35 & 0,35 & 0,35 & 0,35 & 0,35 & 0,35 & 0,35 \\
\hline $\mathrm{M}$ & 0,30 & 0,30 & 0,30 & 0,30 & 0,30 & 0,30 & 0,30 & 0,30 & 0,30 & 0,30 & 0,30 & 0,30 & 0,30 \\
\hline $\mathrm{N}$ & - & 5,5 & 11 & 16 & 16 & 16 & 20,25 & 20,25 & 20,25 & 20,25 & 20,25 & 20,25 & 20,25 \\
\hline
\end{tabular}

Fonte: Do autor (2019) 
As formulações foram pesadas e submetidas ao processo de moagem por via úmida no moinho periquito no tempo de 19 minutos. Foram realizados testes de densidade, tempo de escoamento e resíduo em malha 325 mesh de todos os testes.

\subsubsection{Parâmetros de controle do engobe}

A Tab.5 apresenta a variação dos parâmetros reológicos como densidade, tempo de escoamento e resíduo dos 13 testes desenvolvidos.

Tabela 5: Caracterização do engobe.

\begin{tabular}{ccc}
\hline Parâmetros & Padrão & Testes \\
\hline Densidade $\left(\mathrm{g} / \mathrm{cm}^{3}\right)$ & 1,77 & $1,77-1,79$ \\
Tempo de escoamento $(\mathrm{s})$ & 60 & $50-60$ \\
Resíduo \#325 (\%) & 1 & $0,5-1$ \\
\hline
\end{tabular}

Fonte: Do autor (2019)

Como pode ser observado na Tab.5 os resultados de caracterização dos testes, para densidade ficaram entre 1,77 e $1,79 \mathrm{~g} / \mathrm{cm}^{3}$, valores estes aproximados do padrão que é $1,77 \mathrm{~g} / \mathrm{cm}^{3}$. Para o tempo de escoamento os testes ficaram entre 50 e 60 segundos compatíveis ao padrão que é até 60 segundos e o percentual do resíduo dos testes analisados ficou entre 0,5 e $1 \%$ dentro do especificado pelo padrão que é de até $1 \%$. Mesmo com uma variação, os resultados foram satisfatórios já que se aproximaram ao engobe padrão. A densidade foi mensurada com picnômetro e o tempo de escoamento com copo Ford $\mathrm{n}^{\circ} 4$. O resíduo foi mensurado com a passagem de uma alíquota da barbotina em malha 325 mesh. Os parâmetros apresentados como padrão na Tab. 5 são comumente utilizados na cerâmica.

Após a moagem, as barbotinas dos 13 engobes testes foram aplicadas em suporte cerâmico seco utilizando binil de $0,2 \mathrm{~mm}$ e a cima do engobe foi aplicado um esmalte comercial com binil de $0,3 \mathrm{~mm}$. A Fig. 8 representa um dos testes (teste 12) aplicados no suporte cerâmico, assim como a camada de esmalte (parte inferior da peça). $\mathrm{O}$ suporte cerâmico foi queimado em forno laboratorial na temperatura de $1100^{\circ} \mathrm{C}$ no ciclo de 25 minutos. Após a queima foram realizados ensaios de avaliação visual e marca d'água. 


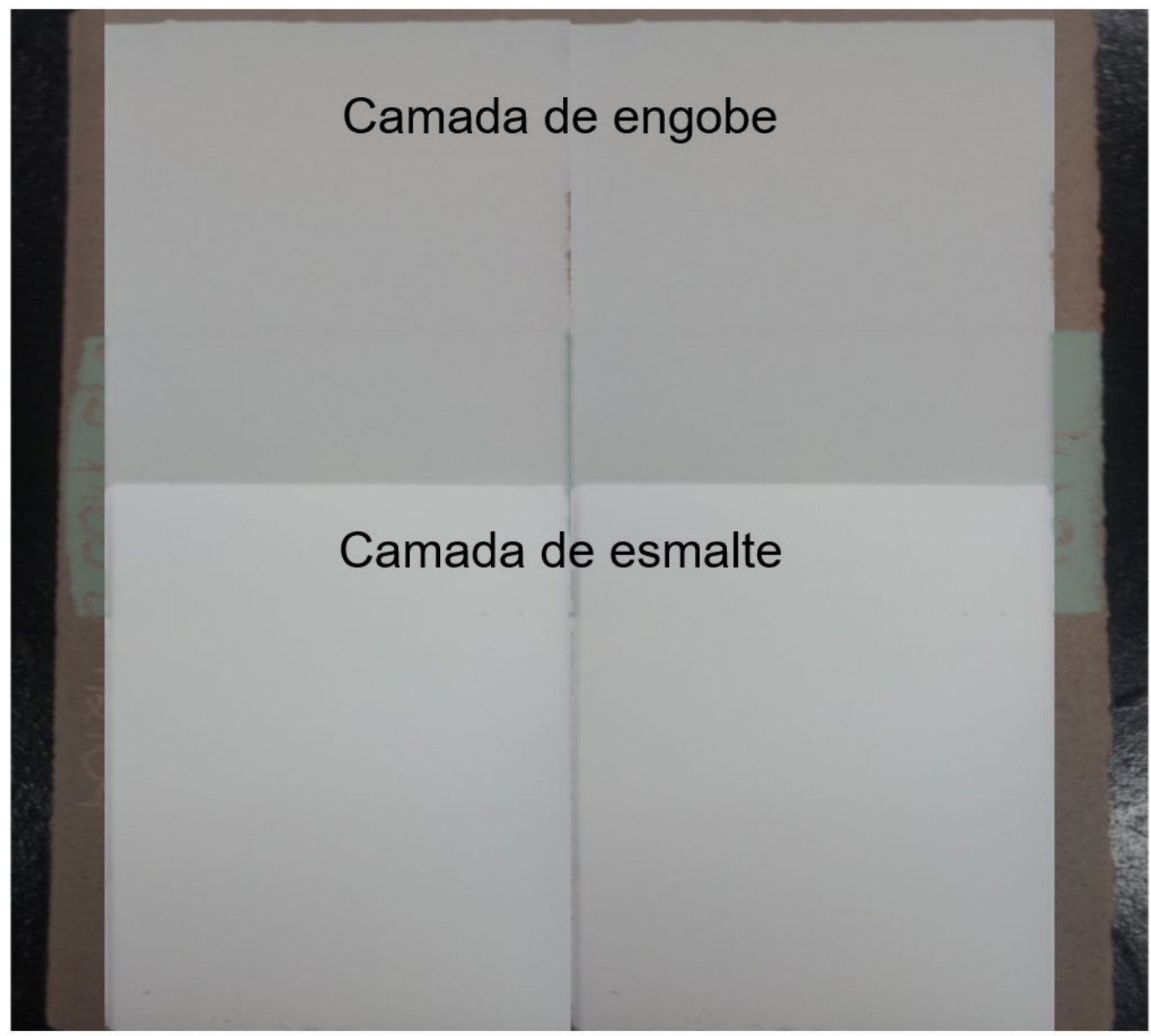

Figura 8: Suporte cerâmico com aplicação do engobe teste juntamente com o esmalte. Fonte: Do autor (2019)

\subsection{ETAPA 5: AVALIAÇÃO DOS RESULTADOS}

Mediantes aos 13 testes realizados em laboratório, o que obteve melhor desempenho foi o teste 12 . Como critério foi avaliado as peças pós-queima fundamentados no método de análise visual de defeitos e na experiência técnica industrial.

Houve a necessidade de realizar diferentes formulações (13 testes), com variações no percentual das matérias primas utilizadas assim como da frita produzida, pois a frita apresentou fusibilidade no engobe, característica essa verificada visualmente nas peças cerâmicas pós queima. A fusibilidade dos engobes influencia diretamente na capacidade de eliminação dos gases oriundos do substrato, entretanto a redução da fusibilidade aumenta a permeabilidade aos gases, ou seja, aumenta a tendência ao aparecimento de macha d'água, por isso é necessário ter um equilíbrio na formulação.

$\mathrm{O}$ teste 12 foi o que apresentou maior opacidade, característica que proporciona maior cobertura do substrato e diminui as imperfeições da superfície. Escolhido o melhor teste (teste 12), foi realizada a aplicação e queima de semi-industrial em uma cerâmica da região. A Fig. 9 apresenta o revestimento cerâmico com aplicação do engobe teste 12 e um esmalte comercial. 


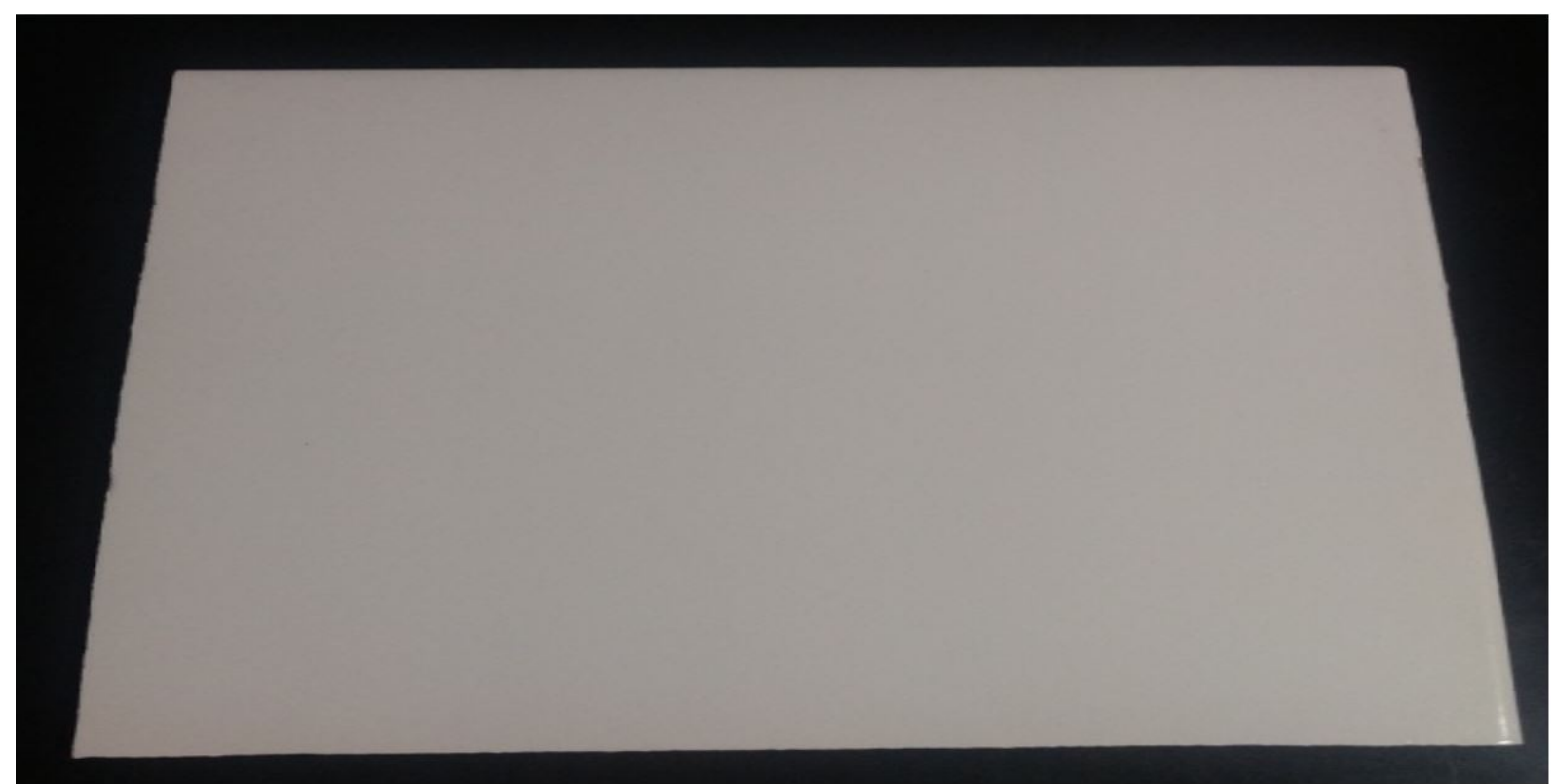

Figura 9: Revestimento cerâmico com aplicação do engobe teste 12 e esmalte comercial. Fonte: Do autor (2019)

Com a peça desenvolvida no processo semi-industrial foi realizado o ensaio de mancha d'água no revestimento cerâmico. $\mathrm{O}$ resultado foi satisfatório, pois após o ensaio o teste não apresentou variações na sua tonalidade. A Fig.10 apresenta o revestimento durante o ensaio sendo que após ensaio, o mesmo retornou ao seu estado inicial conforme Fig.9.

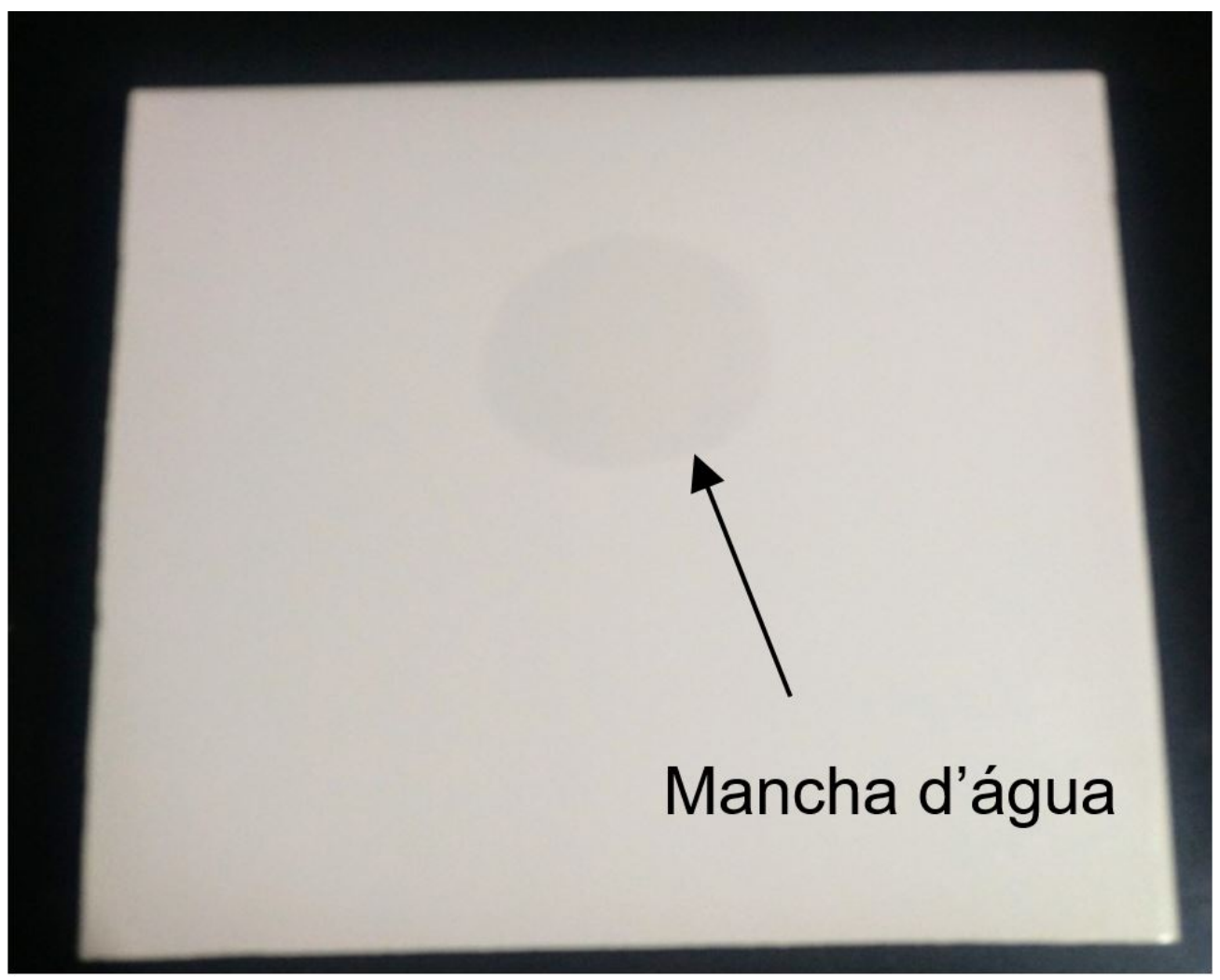

Figura 10: Ensaio de mancha d'água. Fonte: Do autor (2019) 
O ensaio de dilatação realizado no equipamento de análises térmicas apresentou resultado demonstrado na Fig. 11.

\section{BP ENG. COLORMINAS COLORIFÍCIO E MINERAÇÃO S/A}

SISTEMA DE ANÁLISES TÉRMICAS MODELO RB - 3000 - 20
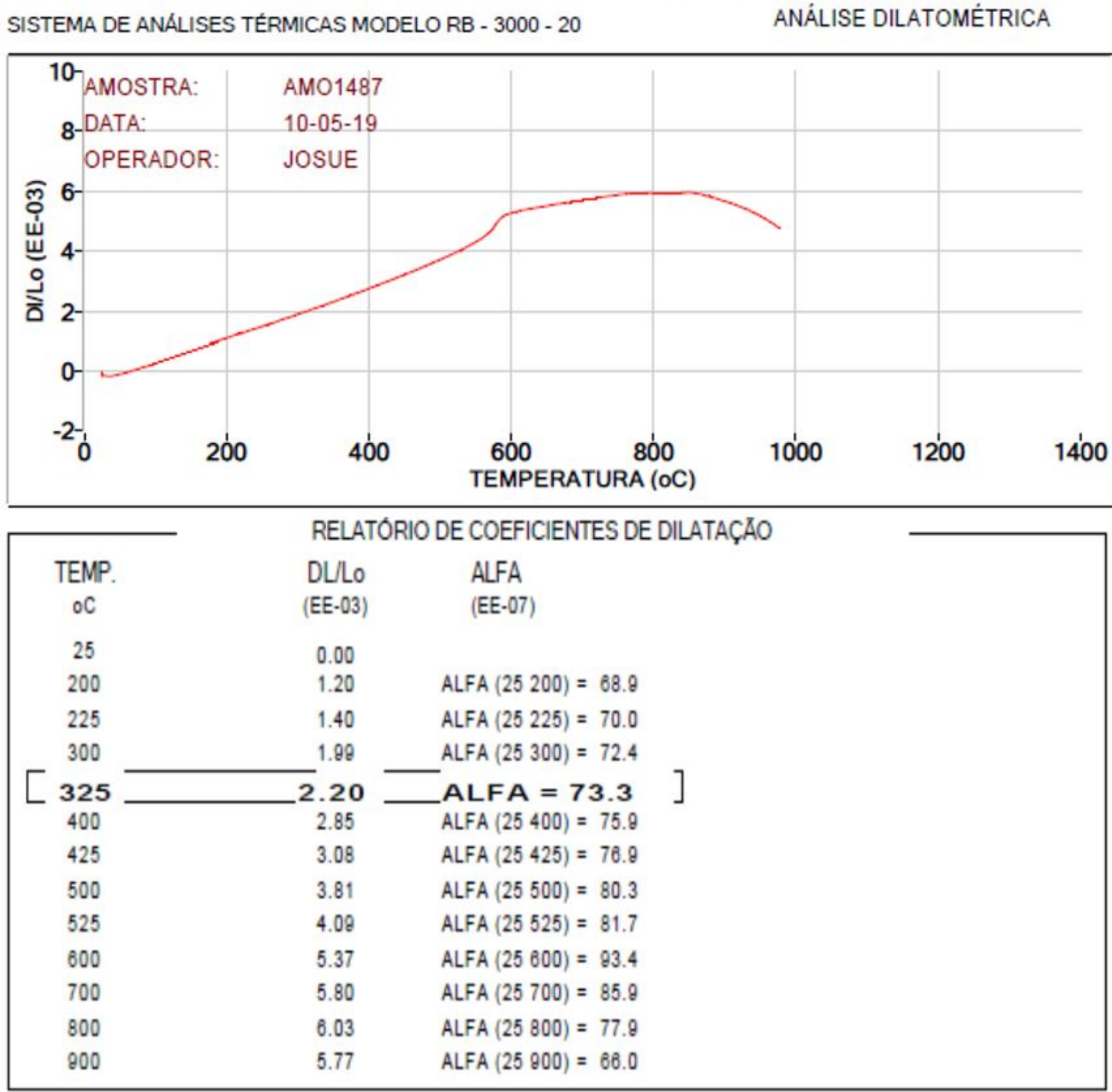

Figura 11: Ensaio de dilatação do engobe teste 12. Fonte: Do autor (2019)

O coeficiente de dilatação térmica encontrado foi de $73,3 \times 10^{-7 \circ} \mathrm{C}^{-1}$ na temperatura de $325^{\circ} \mathrm{C}$ (temperatura utilizada como base). Os coeficientes de dilatação térmica dos engobes comerciais utilizados pela empresa variam de 58 a $88 \times 10^{-7 \circ} \mathrm{C}^{-1}$, o que demonstra que o engobe (teste 12) desenvolvido está dentro dos parâmetros de comercialização.

Mediante aos ensaios obteve-se um engobe com maior fusibilidade, entretanto com a análise visual pode-se perceber menor brancura e com mancha d'água mais perceptível. Com o avanço do estudo, buscou-se corrigir essas características, contudo o engobe apresentou-se mais refratário, o que interfere diretamente na sua retração após queima. Mesmo com esses contrapontos o desempenho do engobe 
desenvolvido foi satisfatório, já que diferenças em relação à brancura e mancha d'água não são significativas para descaracterizar o produto.

\section{CONCLUSÕES}

O estudo do reaproveitamento de resíduo, proveniente da produção de carvão vegetal, na fabricação de frita cerâmica para posterior uso em engobes cerâmicos foi avaliado.

Os resultados induziram a viabilidade técnica devido a bons resultados apresentados durante o processo. Foram realizados 13 testes utilizando a frita com o resíduo de finos como matéria prima, sendo que o teste 12 foi o que apresentou o melhor resultado.

A formulação 12 foi desenvolvida com 3\% de frita produzida com finos de carvão vegetal. Este engobe apresentou bom desempenho quanto à cobertura do suporte cerâmico, a parâmetros de reologia, mancha d'água, e ensaio de dilatação, evidenciando o potencial da frita desenvolvida.

O estudo evidenciou o desenvolvimento de um novo produto utilizando o resíduo do carvão vegetal, unindo otimização de processo e sustentabilidade. Como sugestões para trabalhos futuros podem-se destacar: a produção da frita desenvolvida em escala industrial, o aperfeiçoamento do engobe desenvolvido com a utilização de outras matérias primas que melhorem as características do produto final e o levantamento da redução de custos utilizando o resíduo de finos de carvão vegetal como matéria prima na formulação de fritas.

\section{AGRADECIMENTOS}

Agradeço a Deus, aos meus pais Valda e José, e todas as pessoas que me incentivaram e ajudaram durante essa trajetória. A Empresa Colorminas Colorifício e Mineração S.A. pela disponibilização do ambiente e pelo suporte durante a realização do estudo.

\section{REFERÊNCIAS}

ASSIS,Claudinéia Olimpia de. Sistema alternativo para carbonização de madeira. Dissertação (Mestrado) - Engenharia Florestal, Universidade Federal de Lavras, Minas Gerais, 2007. Disponivel em:

<http://repositorio.ufla.br/bitstream/1/2731/2/DISSERTA\%C3\%87\%C3\%830_Sistema\%20alternativo\%20de\%20carboniza \%C3\%A7\%C3\%A3o\%20da\%20madeira.pdf>. Acesso em: 7 set. 2018.

BENITES, Vinícius de Melo; TEIXEIRA, Wenceslau Geraldes; REZENDE, Maria Emília; PIMENTA, Alexandre Santos.Utilização de carvão e subprodutos da carbonização vegetal na agricultura: aprendendo com as Terras Pretas de Índio. Brasília, 2009. Disponível em: < https://ainfo.cnptia.embrapa.br/digital/bitstream/item/63539/1/Cap-22Vinicius.pdf> . Acesso em: 7 set. 2018.

CEMIN, Daniela da Silveira. Desenvolvimento de um forno para carbonização de resíduos agroflorestais em pequena escala. Dissertação (Mestrado) - Faculdade de Tecnologia, Universidade de Brasília, Brasília/ DF, 2010. Disponivel em http://repositorio.unb.br/bitstream/10482/8160/1/2010_DanieladaSilveiraCemin_completa.pdf . Acesso em: 7 set. 2018.

CÉSAR, Janaína; PAOLI, Marco-Aurélio de; ANDRADE, João Carlos de. A determinação da densidade de sólidos e líquidos.Chemkeys. Disponível em: http://objetoseducacionais2.mec.gov.br/bitstream/handle/mec/11544/articlel.pdf?sequence=3. Acesso em: 15 nov.2018.

CETEC - FUNDAÇÃO CENTRO TECNOLÓGICO DE MINAS GERAIS. Carvão vegetal: Destilação; Carvoejamento; Propriedades; Controle de qualidade.Belo Horizonte: CETEC, 1982. $173 \mathrm{p}$

COELHO, Jorge Luiz. Utilização do resíduo de beneficiamento mineral de uma rocha com espudomênio no desenvolvimento de fritas e esmaltes cerâmicos.Dissertação (Mestrado) - Faculdade de Engenharia de Minas, Metalúrgica e de Materiais, Universidade Federal do Rio Grande do Sul, Porto Alegre, 2014. Disponível em: <http://www.scielo.br/scielo.php?pid=S0366-69132016000100004\&script=sci_abstract\&tlng=pt> . Acesso em: 18 set. 2018.

GUARDABASSI, Patria Maria. Sustentabilidade da biomassa como fonte de energia: perspectivas para países em desenvolvimento. 2006. 132 f. Dissertação (Mestrado em Energia)-Universidade São Paulo, São Paulo, 2006. Disponível em: <http://www.iee.usp.br/producao/2006/Teses/Dissertacao_Guardabassi.pdf>. Acesso em: 07 set. 2018.

HERAS, Federico Michavila. A Evolução das Fábricas de Fritas, Esmaltes e Corantes Cerâmicos e sua Contribuição para o Setor Cerâmico. Cerâmica Industrial, São Paulo, v.07, n. 04, p. 7-17, jul/ago. 2002. Disponível: http://www.ceramicaindustrial.org.br/pdf/v07n04/v7n4_1.pdf. Acesso em: 18 set. 2018. 
IBGE - Instituto Brasileiro de Geografia e Estatística. Produção da extração vegetal e silvicultura, Rio de Janeiro, v. 31 , p. 154, 2016. Disponível em: <https://biblioteca.ibge.gov.br/visualizacao/periodicos/74/pevs_2016_v31.pdf>. Acesso em: 01 set. 2018.

JUNIOR, Marsis Cabral; BOSCHI, Anselmo; FERREIRA, André Luiz Baradel; COELHO, José Mario. A Indústria de Colorifícios no Brasil: Situação Atual e Perspectivas Futuras. Cerâmica Industrial. São Paulo, v. 15, n. 01, p. 13-18, 2010. Disponível em: <http://www.ceramicaindustrial.org.br/pdf/v15n1/v15n1a02.pdf>. Aceso em: 18 set.2018.

JUVILLAR, J. B. Tecnologias da transformação da madeira em carvão vegetal. In: PENEDO, W. R. (Comp.). Uso da madeira para fins energéticos. Belo Horizonte: CETEC, 1980. 158 p. (Série Publicações Técnicas, n. 1).

LIMA, Maria Margarida Teixeira Moreira. Características da poeira do processo de fabricação de materiais cerâmicos para revestimento: estudo no pólo de Santa Gertrudes. 2007. 142f. Dissertação (Pós-Graduação) - Faculdade de Engenharia Civil, Arquitetura e Urbanismo, Universidade Estadual de Campinas, Campinas, 2007. Disponível em: <http://repositorio.unicamp.br/bitstream/REPOSIP/257818/1/Moreira-Lima_MariaMargaridaTeixeira_M.pdf>. Acesso em: 07 out. 2018.

LOUREIRO, Gabrielle Hambrecht. Otimização do carregamento e descarregamento de fornos em uma planta de carbonização. Dissertação (Pós-graduação) - Universidade Federal do Paraná, Curitiba, 2014. Disponível em: <https://acervodigital.ufpr.br/bitstream/handle/1884/46664/R\%20-\%20E\%20\%20GABRIELLE\%20HAMBRECHT\%20LOUREIRO.pdf?sequence=1>. Acesso em: 07 set. 2018.

MONTE, M.V.C.; LIMA, N.B.; AGUIAR, A.A.; OLIVEIRA, R.R.; MENEGAZZO, A.P.M. Avaliação de engobes no aparecimento da mancha de água em revestimentos cerâmicos. $18^{\circ} \mathrm{CBECiMat} \mathrm{-} \mathrm{Congresso} \mathrm{Brasileiro} \mathrm{de} \mathrm{Engenharia} \mathrm{e} \mathrm{Ciência} \mathrm{dos}$ Materiais. Disponível em: < http://repositorio.ipen.br:8080/xmlui/bitstream/handle/123456789/15839/13256. pdf?sequence=1\&isAllowed=y>. Acesso em: 18 set. 2018.

OLIVEIRA, Marcos de. Carvão vegetal sustentável: Novo sistema produz de forma limpa matéria-prima dentro de floresta de eucaliptos. Pesquisa Fapesp, São Paulo, n. 189, p. 72-75, nov. 2011. Disponível em: <http://revistapesquisa.fapesp.br/2011/11/11/carvao-vegetal-sustentavel/>. Acesso em: 02 set. 2018.

SANCHÉS, E. Matérias-Primas para a Fabricação de Fritas e Esmaltes Cerâmicos. Cerâmica Industrial, São Paulo, v.02, n. 34, p. 32-40, mai/ago. 1997. Disponível em: < http://www.ceramicaindustrial.org.br/pdf/v02n34/v2n34_5.pdf>. Acesso em: 18 set. 2018.

SANTOS, Rosimere Cavalcante dos. Parâmetros de qualidade da madeira e do carvão vegetal de clones de eucalipto. Tese (Pós-Graduação) - Ciência e Tecnologia da madeira, Universidade Federal de Lavras, Lavras, 2010. Disponível em: <http://prpg.ufla.br/_ppg/ct-madeira//wp-content/uploads/2012/07/Rosimeire-Cavalcante-dos-Santos-Tese1.pdf>. Acesso em: 1 out. 2018.

SANTOS, Sueli de Fátima de Oliveira Miranda; HATAKEYAMA, Kazuo. Processo sustentável de produção de carvão vegetal quanto aos aspectos: ambiental,econômico, social e cultural. SciELO - ScientificElectronic Library Online. São Paulo,v. 22, n. 2, p. 309-321, mar. 2012. Disponível em: < http://www.scielo.br/scielo.php?pid=S010365132012000200011\&script=sci_abstract\&tlng=pt>. Acesso em: 1 out. 2018.

SARABANDO, Artur R. M.; OLIVEIRA, Helder J. C., LABRINCHA, João António. Uso de Granilhas em Suspensão para Porcelanato. Cerâmica Industrial, São Paulo, v. 16, n. 03, p. 11-16, mai/jun. 2011. Disponível em: $<$ http://www.ceramicaindustrial.org.br/pdf/v16n3/v16n3a02.pdf>. Acesso em: 07 out.2018.

SASAKI, A.C.; LIMA, L. S.; QUINÁIA, S. P. Reaproveitamento de Resíduo de Moinha de Carvão Vegetal para Adsorção de Íons Metálicos em Meio Aquoso. Revista Virtual de Química. Paraná, v. 06, n. 06, p. 1549-1563, Nov. 2014. Disponível em: < http://rvq.sbq.org.br/imagebank/pdf/v6n6a03.pdf>. Acesso em: 18 out. 2018.

ZANATTA, Luiz Otavio da Soler. Estudo da utilização de resíduo sólido proveniente do processo de fabricação de fritas para a produção de esmaltes cerâmicos. Disponível em: <http://repositorio.unesc.net/bitstream/1/1797/1/Luiz\%20Otavio\%20Da\%20Soler\%20Zanatta.pdf>. Acesso em: 30 set. 2018. 